\title{
GENOTYPIC VARIATION ON THE ANTIOXIDATIVE RESPONSE OF COWPEACULTIVARS EXPOSED TO OSMOTIC STRESS ${ }^{1}$
}

\author{
EDILENE DANIEL DE ARAÚJO ${ }^{2 *}$, ALBERTO SOARES DE MELO ${ }^{2}$, MARIA DO SOCORRO ROCHA $^{2}$, REBECA $^{2}$ \\ FERREIRA CARNEIRO ${ }^{2}$, MAURISRAEL DE MOURA ROCHA ${ }^{3}$
}

\begin{abstract}
The cowpea [Vigna unguiculata (L.) Walp.], also known as cowpea, is of fundamental socioeconomic importance to the northeast of Brazil, and has become one of the main sources of protein in the diet of the rural population. However, in this region, it has become necessary to identify genotypes that are better adapted to drought. In addition, research is needed regarding the action of substances that promote tolerance to stress factors. The aim of this study was to evaluate the antioxidative response of cowpea cultivars under osmotic stress conditions using potassium nitrate as an attenuator. Five osmotic potentials were tested in the substrate $(0.0,-0.2,-0.4,-0.6$, and $-0.8 \mathrm{MPa})$, and three seed treatments (pre-soaking in distilled water, pre-soaking in potassium nitrate, and without pre-soaking) were tested in three cowpea cultivars (BRS Itaim, BRS Aracê, and BRS Potengi). The design was randomized with 45 treatments and four replications. The data were submitted to analysis of variance $(P<0.05)$, and in cases of significance, regression analysis was conducted to quantitate the factors. Our results indicate that an increase in proline content in cowpea plants may be seen as indicative of the intensity of water stress on germination and the initial stages of growth of the plant. The BRS Itaim cultivar best tolerates drought conditions with the application of potassium nitrate, given the increased activity of antioxidant enzymes such as superoxide dismutase, catalase, and ascorbate peroxidase.
\end{abstract}

Keywords: Vigna unguiculata. Enzymes. Catalase. Hydrical stress.

\section{VARIAÇÃO GENOTÍPICA NA RESPOSTA ANTIOXIDATIVA DE CULTIVARES DE FEIJÃO-CAUPI EXPOSTOS AO ESTRESSE OSMÓTICO}

RESUMO - O feijão-caupi [Vigna unguiculata (L.) Walp.], também conhecido como feijão macassar, representa fundamental importância socioeconômica para o Nordeste do Brasil, constituindo-se como uma das principais fontes proteicas na alimentação da população rural. Todavia, nessa região é necessário identificar genótipos mais adaptados ao déficit hídrico, bem como conhecer a ação de substâncias promotoras de tolerância a fatores de estresse. O objetivo desse trabalho foi avaliar a resposta antioxidativa de cultivares feijão-caupi sob condições de estresse osmótico, utilizando como atenuador o nitrato de potássio. Foram testados cinco potenciais osmóticos no substrato $(0,0 ;-0,2 ;-0,4 ;-0,6$ e $-0,8 \mathrm{MPa})$ e três tratamentos de sementes (pré-embebição em água destilada; pré-embebição em nitrato de potássio e sem pré-embebição) em três cultivares (BRS Itaim, BRS Aracê e BRS Potengi). Foi adotado o delineamento inteiramente casualizado, com quatro repetições e sementes por repetição. Os dados obtidos foram submetidos à análise de variância $(P<0,05)$ e nos casos de significância foi realizada a análise de regressão para fator de natureza quantitativa. Os resultados indicam que um aumento no teor de prolina em feijão-caupi pode ser visto como indicativo da intensidade do estresse hídrico na germinação e nos estágios iniciais de crescimento da planta. A cultivar BRS Itaim tolera melhor as condições de seca com a aplicação de nitrato de potássio,dado o aumento da atividade de enzimas antioxidantes como superóxido dismutase, catalase e ascorbato peroxidase.

Palavras-chave: Vigna unguiculata. Enzimas. Catalase. Estresse hídrico.

\footnotetext{
*Corresponding author

${ }^{1}$ Received for publication in 08/14/2016; accepted in 03/06/2017.

Paper approved from IV CONAC 2016.

${ }^{2}$ Department of Agrarian Sciences, Universidade do Estado da Paraíba, Campina Grande, PB, Brazil; araujo.biologiauebp@outlook.com, alberto@uepb.edu.br, marialirium@hotmail.com, rebecafc90@hotmail.com.

${ }^{3}$ Embrapa, Teresina, PI, Brazil; maurisrael.rocha@embrapa.br.
} 


\section{INTRODUCTION}

Cowpea [Vigna unguiculata (L.) Walp.], also known as "feijão-de-corda" and "feijão-macassar," is one of the main food sources in the north and northeast regions of Brazil, and is a basic food of the low-income population (NASCIMENTO et al., 2011); in addition to its nutritive importance, it generates employment and income for these regions (FREIRE FILHO, 2011).

As with other crops of economic importance, the cowpea is subject to various abiotic factors that affect its growth, development, and yield. Among these factors, water availability is the most limiting. In northeast Brazil, water scarcity is a common condition that reduces the yield of cowpea and other important crops (MENDES et al., 2007).

This reduction in water availability can affect the metabolism of the plant by leading to morphophysiological and biochemical alterations such as reduction of leaf area, stomatal closure, growth of the root system, and increase in enzymatic activity (TAIZ; ZEIGER, 2013).

In addition to restrictions in nutrient acquisition, water stress causes oxidative stress through excessive production of reactive oxygen species (ROS). To eliminate ROS, plants use antioxidant enzymatic systems that produce superoxide dismutase (SOD), catalase (CAT) and ascorbate peroxidase (APX) as their primary defense against these free radicals (LISAR et al., 2012).

Potassium nitrate has been studied in various agricultural crops to understand its mechanisms of action in species such as melon (ANDRADE JÚNIOR et al., 2011), "pau-d'dalho" (LOPES et al., 2015), and cabbage (KAISER et al., 2016), cultivated under saline conditions. However, studies related to potassium nitrate and water deficiency in cowpea remain scarce.

This study aimed to characterize the morphophysiological and antioxidative responses of cowpea genotypes to water-deficit conditions, using potassium nitrate as an attenuator.

\section{MATERIAL AND METHODS}

The study was carried out from January to May 2016, in the Laboratory of Ecophysiology of Cultivated Plants (ECOLAB), located in the Três Marias Integrated Research Complex, at the State University of Paraíba, Campus I, Campina Grande, Paraíba.

Three cowpea cultivars were used (BRS Itaim, BRS Aracê, and BRS Potengi), in a $3 \times 3 \times 5$ factorial scheme,subjected to three conditions in the pre-sowing $(\mathrm{NI}=$ no imbibition; IPW $=$ imbibition in purified water, and IPN = imbibition in potassium nitrate $\left.\left[10^{-5} \mathrm{M}\right]\right)$. Imbibition treatments were 8 hours long with five different water potentials, induced by polyethylene glycol 6000 (PEG 6000), during germination and initial growth $(-0.8,-0.6,-0.4$, $-0.2 \mathrm{MPa}$, and $0=$ purified water), which, factorially combined, resulted in 45 treatments.

The seeds were initially selected to eliminate those with physical or biological damage and/or malformation. After selection, they were weighed and transferred to a spinning roll, built using PVC

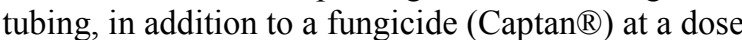

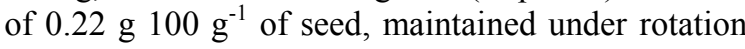
for 5 minutes; afterward, the seeds remained at rest for 24 hours. After this period, the seeds were divided into three groups, two of which were wrapped in rolls of paper towel (BRASIL, 2009) for later imbibition in potassium nitrate solution $\left(10^{-5} \mathrm{M}\right)$ indistilled water for a period of 8 hours. The third group was maintained in a polyethylene terephthalate bottle, sealed for the same period, to avoid any alteration in the moisture content of the seeds.

After the imbibition period, all seeds were distributed into acrylic boxes (Gerbox $\left.{ }^{\circledR}\right)$, 50 seeds per box, containing four sheets of Germitest ${ }^{\circledR}$ paper, previously moistened with purified water and osmotic solutions of PEG $6000(-0.8,-0.6,-0.4$, and $-0.2 \mathrm{MPa}$ ) at a proportion of $2.5 \mathrm{~g} \mathrm{~g}^{-1}$ of paper. The boxes were then sealed with plastic film and weighed on an analytical scale to obtain the total weight (box + paper + seeds + plastic film), which was used as a reference in the daily replacement of water. Last, the boxes were placed in a biochemical oxygen demand germination chamber regulated at $27 \pm 2{ }^{\circ} \mathrm{C}$ with a photoperiod of 12 hours (BRASIL, 2009), where they remained for 14 days. Water consumption was monitored daily by weighing the boxes; the water was replaced until the initial weight of the set (box + paper + seeds + plastic film) was achieved.

The quantity of PEG 6000 necessary for each osmotic solution was determined using the equation proposed by Michel and Kaufmann (1973). The dilution was performed in $200 \mathrm{~mL}$ of purified water $\left(25^{\circ} \mathrm{C}\right)$, which was then added to $100 \mathrm{~mL}$ of the same solvent. Last, the solution was maintained in sealed glass flasks at ambient temperature to minimize water loss and, consequently, any alteration in the potential, until the moment of use.

Over the 13 days of the experiment, germination was evaluated by counting, considering as germinated seeds those with a radicle with a minimum length of $2 \mathrm{~mm}$ (REHMAN et al., 1996). These data were used to calculate the final germination percentage $(\mathrm{G} \%)$ and germination speed index (GSI) (CARVALHO; CARVALHO, 2009).

After radicle lengths were measured, with a ruler in centimeters, the parts of the seedlings (stem) were organized separately in paper bags, properly identified, and placed in a forced-air oven at a temperature of $65^{\circ} \mathrm{C}$ for 48 hours, after which, the total dry phytomass (TDP) was obtained using an 
analytical scale.

At the end of the experiment (14th day), the primary leaves (PL) of the most representative and tallest seedling of each treatment were randomly collected to quantify the activities of the antioxidant enzymes (SOD, APX, and CAT) and proline as an indicator of osmoregulation.

For enzymatic extraction, $200 \mathrm{mg}$ of the fresh material (leaf) was ground, separately, in $2 \mathrm{~mL}$ of potassium phosphate buffer (final concentration, $50 \mathrm{mM}$; final $\mathrm{pH} 7$ ) added to ascorbic acid (0.1 mM), ethylenediaminetetraacetic acid $(0.1 \mathrm{mM})$, and polyvinylpyrrolidone $(5 \%)$. The extracts were then centrifuged at $20,000 \mathrm{rpm}$ at a temperature of $4^{\circ} \mathrm{C}$ for 15 minutes. The supernatant was vacuumed, allocated in Eppendorf ${ }^{\mathbb{B}}$ tubes, and maintained in a refrigerator until the analyses.

CAT activity was measured following the oxidation of $\mathrm{H}_{2} \mathrm{O}_{2}$ at $240 \mathrm{~nm}$. The enzymatic reaction of the extract was determined in the presence of the $50 \mathrm{mM}$ potassium phosphate buffer $(\mathrm{pH}$ 7.0) containing $20 \mathrm{mM}$ of $\mathrm{H}_{2} \mathrm{O}_{2}$. The reaction was monitored every 15 seconds, at an absorbance of $240 \mathrm{~mm}$, for 90 seconds (SUDHAKAR; LAKSHMI; GIRIDARAKUMAR, 2001). CAT activity was expressed in nanomoles of $\mathrm{H}_{2} \mathrm{O}_{2}$ per gram of fresh matter per minute. Proline concentration was determined according to the methodology described by Bates, Waldren and Teare (1973), determined based on the standard curve of L-Proline, with results expressed in nanomoles per gram of fresh matter and the reading was performed in a spectrophotometer at $520 \mathrm{~nm}$ of absorbance.

The activity of the SOD was determined by the inhibition of the photoreduction of the nitrotetrazole blue chloride (BEAUCHAMP; FRIDOVICH, 1971). Aliquots of $0.1 \mathrm{~mL}$ of the protein extract were transferred to test tubes containing reaction medium composed of the $50 \mathrm{mM}$ potassium phosphate buffer ( $\mathrm{pH}$ 7.8), ethylenediaminetetraacetic acid $(0.1 \mathrm{mM})$, L-methionine (13 $\mathrm{mM})$, and nitrotetrazole blue chloride $(75 \mu \mathrm{M})$.

The reaction was initiated by the addition of $2 \mu \mathrm{M}$ riboflavin, followed by illumination of the reaction medium with $30-\mathrm{W}$ fluorescent lamps in a closed box. After 5 minutes, the reaction was interrupted by turning off the lights; the readings were performed at $560 \mathrm{~nm}$. One unit of the SOD activity was expressed in $\mathrm{UA}^{-1}$ dry matter per minute.

To measure APX activity, the consumption of ascorbate was detected by the decrease in absorbance at $290 \mathrm{~nm}$ (NAKANO; ASADA, 1981). Aliquots of $0.1 \mathrm{~mL}$ of the extract were transferred to test tubes containing $2.7 \mathrm{~mL}$ of the $50 \mathrm{mM}$ potassium phosphate buffer ( $\mathrm{pH}$ 6.0) and $0.8 \mathrm{mM}$ L-ascorbate.
The reaction was initiated by the addition of hydrogen peroxide $(2 \mathrm{mM})$ and the enzymatic activity was expressed in nanomoles of per gram of fresh matter per minute.

The experimental design was completely randomized, with four replicates; the experimental plot comprised 50 seeds (BRASIL, 2009). The data of the response variables were subjected to analysis of variance by $\mathrm{F}$ test $(P \leq 0.05)$ and the regression models, for the quantitative factor, were fitted according to the coefficient of determination up to a 0.05 significance level. The analyses and graphs were made using Sisvar v. 5.3, Microsoft Excel, and Table Curve 2D.

\section{RESULTS AND DISCUSSION}

There was significant interaction between the seedlings that were soaked and not soaked in distilled water and potassium nitrate and subjected to water potentials for the GSI, G\%, seedling height $(\mathrm{SH})$, total dry phytomass (TDP), activities of superoxide dismutase (SOD, CAT, APX, and proline (Figures $1-4)$.

The observation of the germination capacity of seeds under stress is one of the most common methods for determining the tolerance level of plants, as it corresponds to one of the most critical stages in the plant life cycle (MOTERLE et al., 2008).

The highest GSI values were equal to 0.9 IPW (Figure 1A), IPN (Figure 1C), and dry weight (Figure 1E) at $0.0 \mathrm{MPa}$, respectively. The reductions were estimated from the values of $50 \%$ NI, $44.44 \%$ IPW, and 62.50 IPN for the cultivar BRS Itaim, obtained through a decreasing quadratic fit, in the seeds hydroconditioned in solutions with a water potential of $0 \mathrm{MPa}$, for the respective variables.

The results in Figure $1(\mathrm{~B}, \mathrm{D}$, and $\mathrm{F})$ demonstrate that the imbibition in PN for the three cultivars (BRS Itaim, BRS Aracê, and BRS Potengi) positively influenced the germination percentage at the water potential of $-0.4 \mathrm{MPa}$, despite showing a slight reduction in comparison to the potential of $-0.8 \mathrm{MPa}$. The imbibitions of the seeds rapidly reach stage II in which there is enzyme activation for the membranes and organelles, such as mitochondria, responsible for the digestion of the reserves (carbohydrates, proteins, and lipids). This results in the increase in the concentration of metabolites in the cell protoplasm and, consequently, a decrease in the osmotic potential (more negative water potential) in the seed (GUIMARÃES; DIAS; LOUREIRO, 2008), which limits water loss to the substrate because movement of water occurs from a region of higher water potential (less negative) to a region of lower water potential (more negative). 

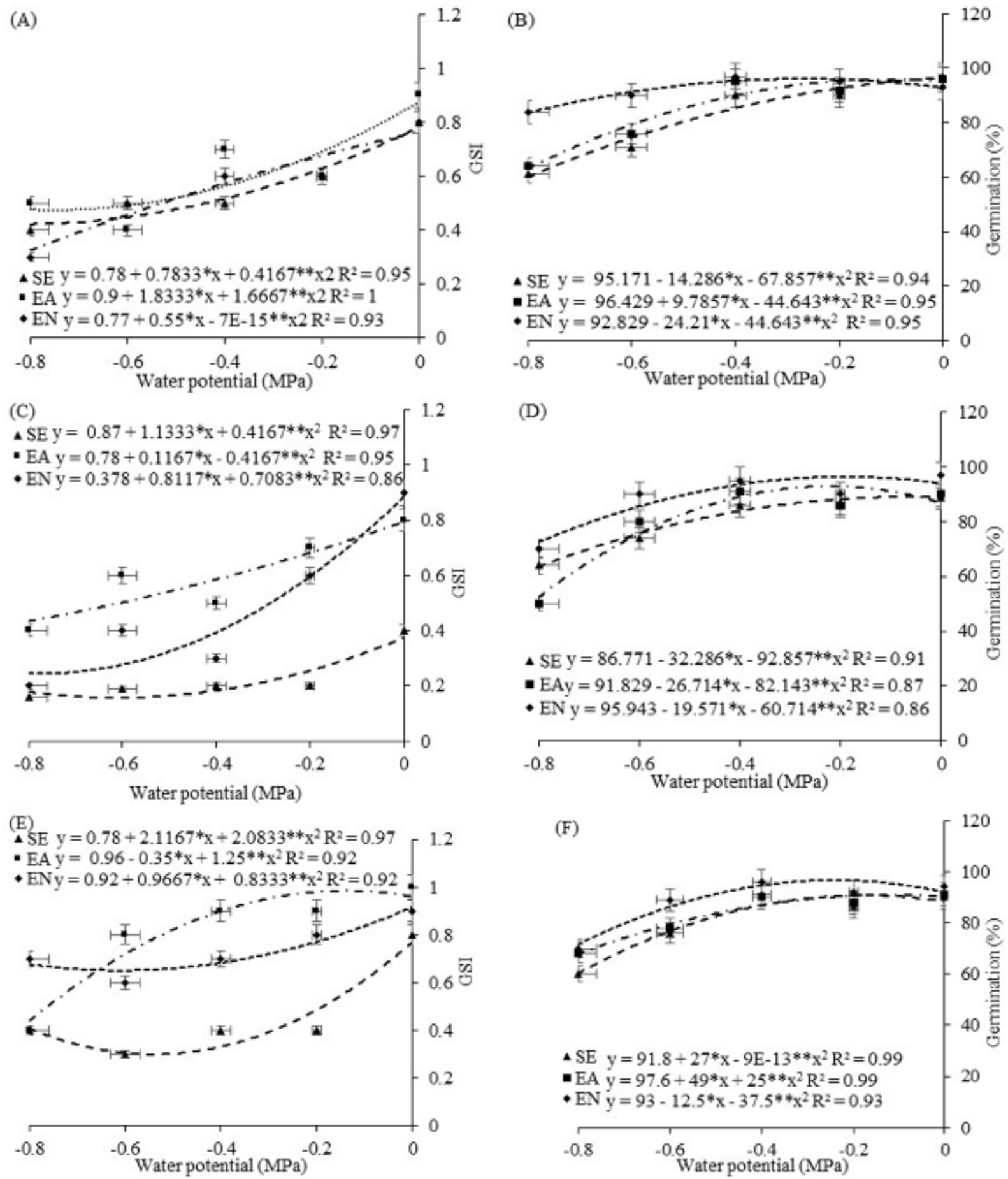

Figure 1. Germination speed index - GSI (A, C and E), Germination - G (B, D and F) of the cowpea cultivars: 'BRS Itaim' (A and B), 'BRS Aracê' (C and D) and 'BRS Potengi' ( $\mathrm{E}$ and $\mathrm{F}$ ), conditioned during pre-sowing and subjected to different water potentials induced by PEG 6000. NI - no imbibition; IPW - imbibition in purified water and IPN - imbibition in nitrate.

Both iln the absence and presence of PN in the cowpea cultivars, there were higher height values at the water potential of $-0.4 \mathrm{MPa}$ (Figure 2, A, C, and $\mathrm{E}$ ) in the seedlings of three cultivars. In the present study, the decrease in the water potentials negatively influenced seedling height and total dry phytomass (TDP) of the cowpea cultivars, especially those not subjected to imbibition during the pre-sowing (Figure 2). With the imbibition of the seeds in IPN, there was a significant improvement in the growth parameters (seedling height and TDP) of the cowpea cultivars (Figure 2), reinforcing the hypothesis that the IPN acts as an efficient growth regulator and modulator of numerous responses in plants (PRAZERES et al., 2015). ,

The effect of different water potentials on the physiology and morphology of various species, such as common bean (CUSTÓDIO; SALOMÃO; 
MACHADO NETO, 2009; YAMAMOTO et al., 2014), wheat (GIROTTO et al., 2012), and sunflower (HÄTER et al., 2014) has been intensively studied in order to elucidate the effects of water deficiency, as well as the mechanisms of response to the water stress. The authors, evaluating the effect of different water potentials during germination and

(A)
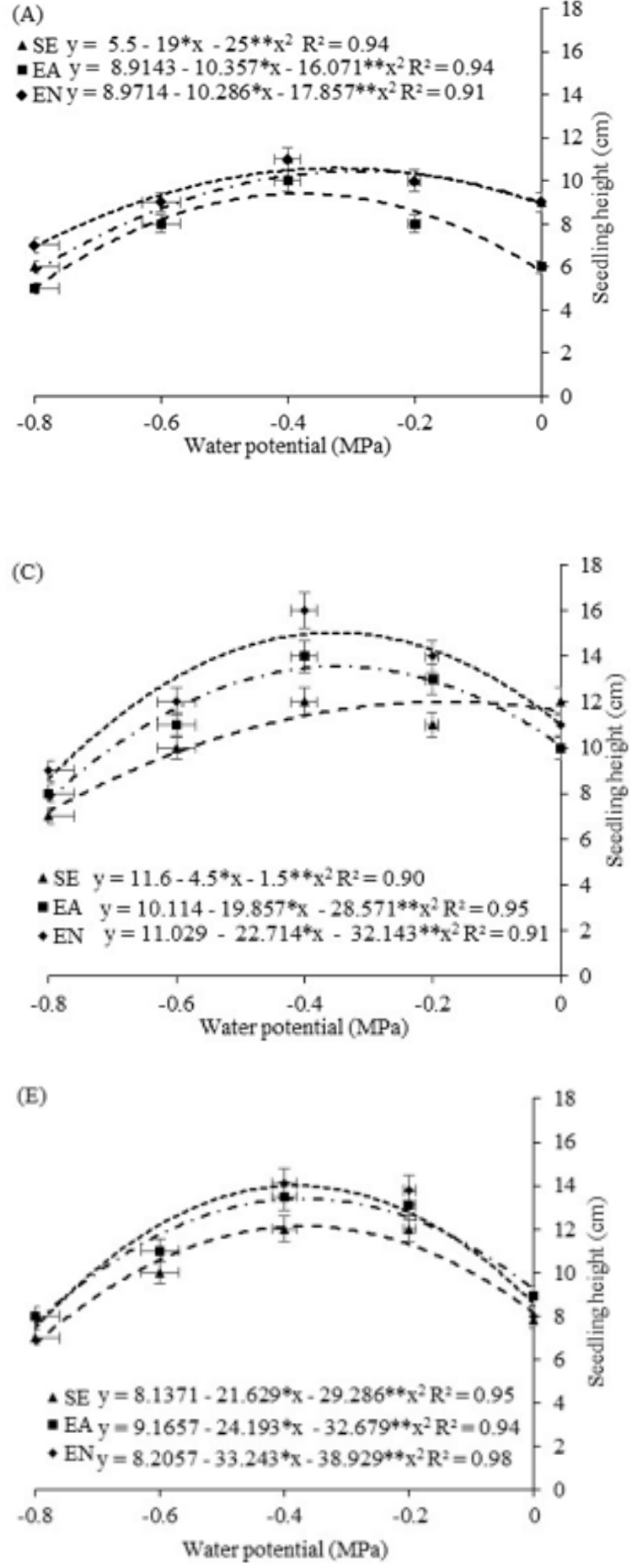

initial growth stages, observed a decrease in growth with an increase in water restriction, a behavior explained by the reduction in cell elongation, with a consequent increase in the synthesis of the secondary wall under water stress (CARVALHO; NAKAGAWA, 2000).
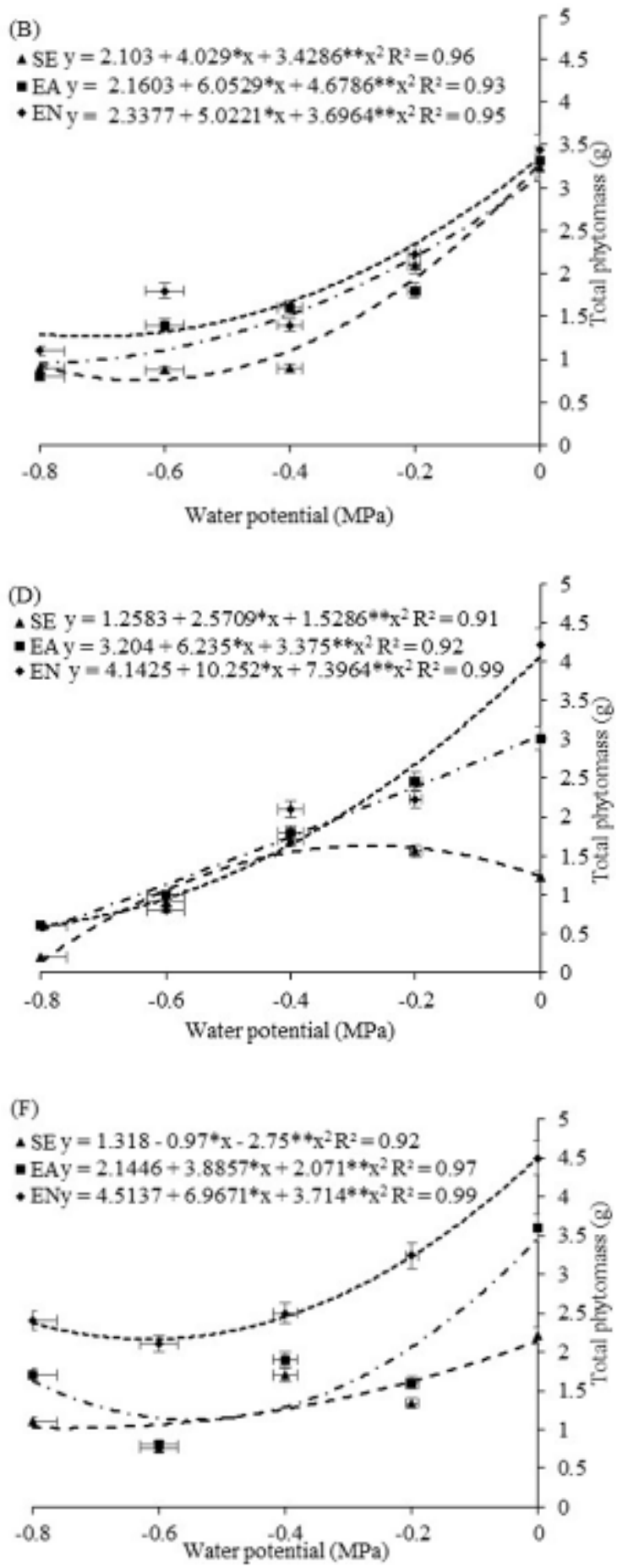

Figure 2. Seedling height - SH (A, C and E), total dry phytomass - TDP (B, D and F) of the cowpea cultivars: 'BRS Itaim' (A and B), 'BRS Aracê' (C and D) and 'BRS Potengi' ( $\mathrm{E}$ and F), conditioned during the pre-sowing and subjected to different water potentials induced by PEG 6000. NI - no imbibition; IPW - imbibition in purified water and IPN - imbibition in nitrate. 
It was possible to observe, in the cowpea seedlings subjected to the most negative potential $(-4.0 \mathrm{MPa})$, that the reduction of growth in seedling height and TDP is dependent on the interaction of conditioning $\times$ cultivar, which is usually higher than $50 \%$. Girotto et al. (2012), evaluating the behavior of wheat genotypes at different water potentials induced by PEG 6000 and mannitol, observed that at a potential of $-0.4 \mathrm{MPa}$, or at more negative potentials, the growth of the seedlings decreased by at least $50 \%$, but varied among the genotypes.

Regarding the cultivars, the greatest increment in TDP was also observed in the cultivar BRS Potengi (0.56 g/plant), whereas the lowest value $(0.20 \mathrm{~g} / \mathrm{plant})$ was observed in the cultivar BRS Itaim (Figure 2B). In these cultivars, the imbibition in PN improved the TDP of the seedlings at the potentials of 0 and $-0.4 \mathrm{MPa}$ (Figure 2B). The same was observed in BRS Potengi subjected to the
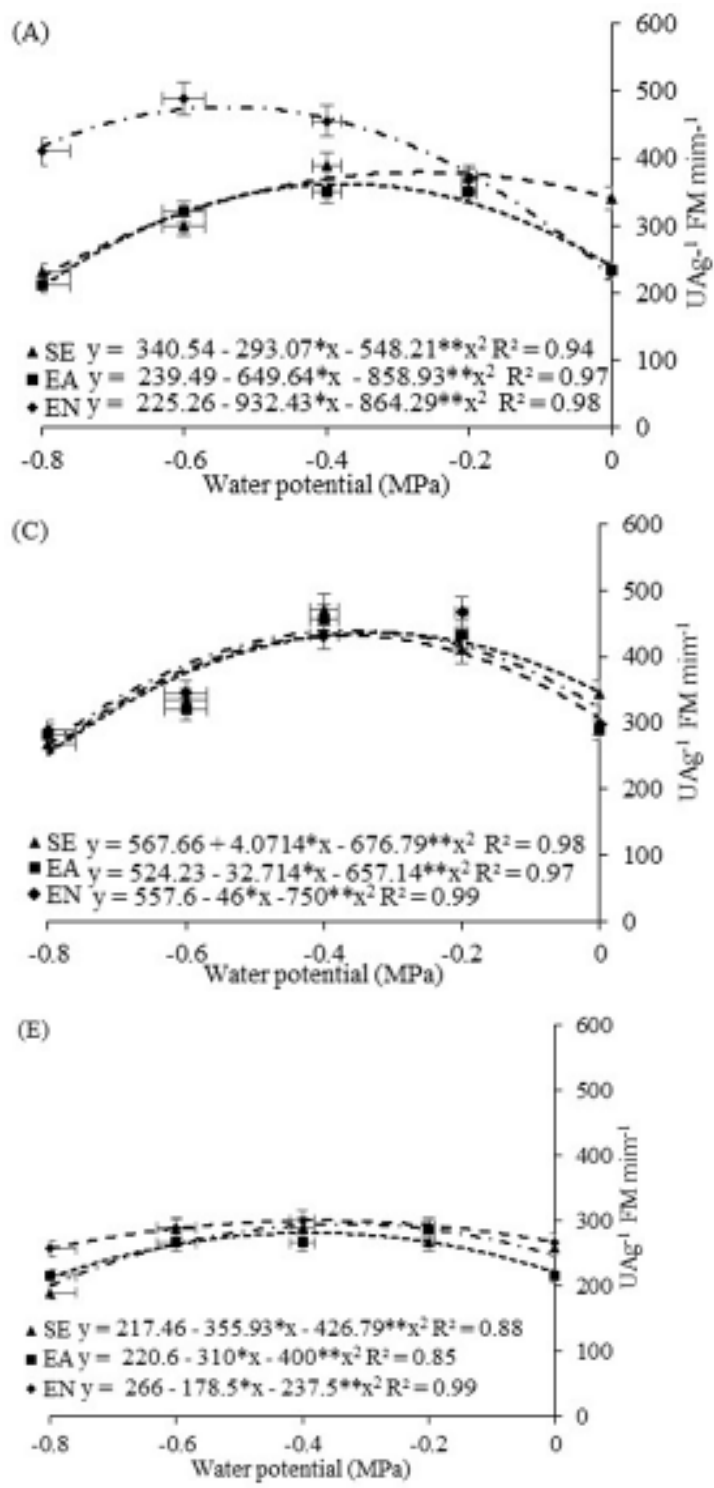

Figure 3. Activity of superoxide dismutase - SOD (A, C and E), Catalase - CAT (B, D and F) of the cowpea cultivars: 'BRS Itaim' (A and B), 'BRS Aracê' ( $C$ and D) and 'BRS Potengi' (E and F), conditioned during the pre-sowing and subjected to different water potentials induced by PEG 6000. NI - no imbibition; IPW - imbibition in purified water and IPN - imbibition in nitrate.

Rev. Caatinga, Mossoró, v. 30, n. 4, p. 928 - 937, out. - dez., 2017 negative potential of $0.4 \mathrm{MPa}$ (Figure $2 \mathrm{~F}$ ). However, at the other potentials, there were no significant differences between the TDP of seedlings from seeds soaked in IPW and IPN (Figure 2B).

Water potential, in addition to the conditioning of the seeds in the pre-sowing, altered SOD activity in the cotyledon leaves (SOD CL) of cowpea (Figure 3). In general, seed imbibition positively influenced SOD CL activity (Figure 3 ).

The imbibition in IPN led to a significant increase in the SOD activity of all cultivars (Figure $3 \mathrm{~A}$ ) when exposed to a water potential of $-0.6 \mathrm{MPa}$. It should be pointed out that the highest SOD value (476.75 $\mathrm{UA} \mathrm{g}^{-1} \mathrm{FM}_{\text {minute }}{ }^{-1}$ ), with the imbibition in IPN, was obtained in BRS Itaim cultivated at the potential of $0.6 \mathrm{MPa}$, of SOD CL between the potentials of -0.6 and $-0.4 \mathrm{MPa}$ (Figure $3, \mathrm{C}$ and $\mathrm{E}$ ), which was superior to all activities recorded in the other cultivars.
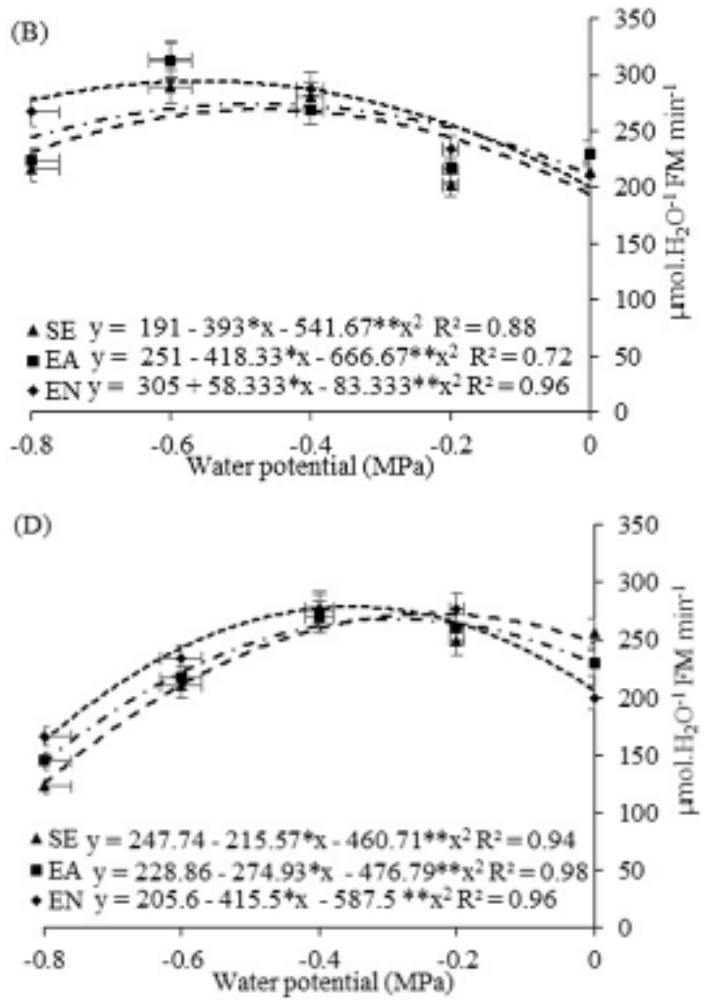

(F)

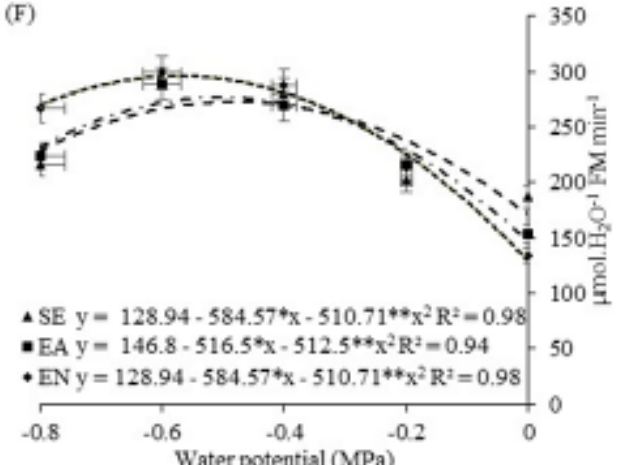


The CAT activity in cotyledon leaves (CAT $\mathrm{CL})$ decreased with the increase in water restriction in all cowpea cultivars (Figure 3, B, D, and F), regardless of the conditioning, and there was a decrease in the activity of this enzyme at the water potential of $-0.4 \mathrm{MPa}$ (Figure 3 ).

The imbibition in IPN significantly influenced CAT CL activity (Figure 3 ) with respect to NI and IPW. It should be highlighted that the imbibition of the seeds in IPW resulted in significantly lower CAT CL activitythan that observed for NI (Figure 3).

The highest values of CAT CL were observed in the cultivar BRS Itaim; the PN led to higher CAT activity in the cotyledon leaves by $315.21 \%$ than did the treatments NI and DW, respectively (Figure 3B).

The occurrence of these environmental stresses can increase or decrease CAT activity in plants, and the behavior depends on the intensity,

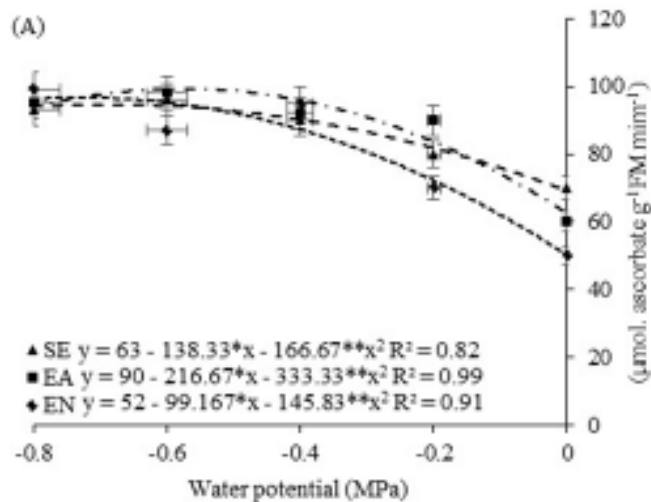

(C)
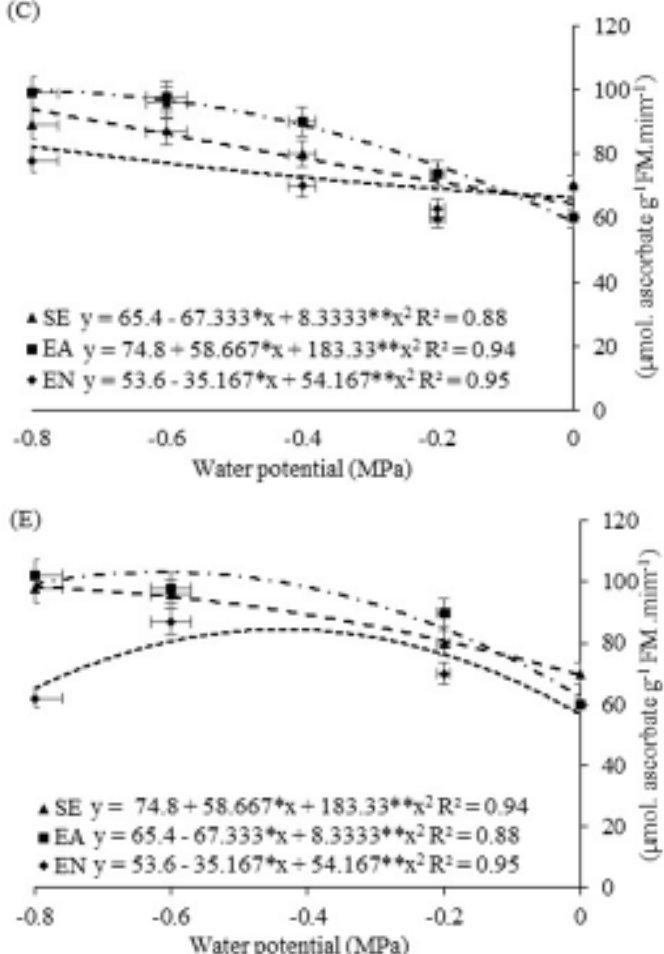

duration, and type of stress (SHARMA et al., 2012). In cowpea subjected to water deficiency, there was an increase in CAT activity in the leaves as the stress become more intense, but it decreased again as the plants were rehydrated (SILVA, 2014). In sunflower plants subjected to different osmotic potentials, there was an increase in CAT activity due to increased water restriction (BALOĞLU et al., 2012). The opposite was observed in rice (SHARMA; DUBEY, 2005) and thale cress (Arabidopsis thaliana) (HE et al., 2014), where CAT activity decreased with increased water stress.

In the present study, APX was more expressive in the leaf (APX L) of all cultivars evaluated. In terms of conditioning, imbibition improved APX activity in the cowpea cultivars, with a superiority of IPW for APX L (Figure 4), whereas the APX L activity was significantly increased with the PN.
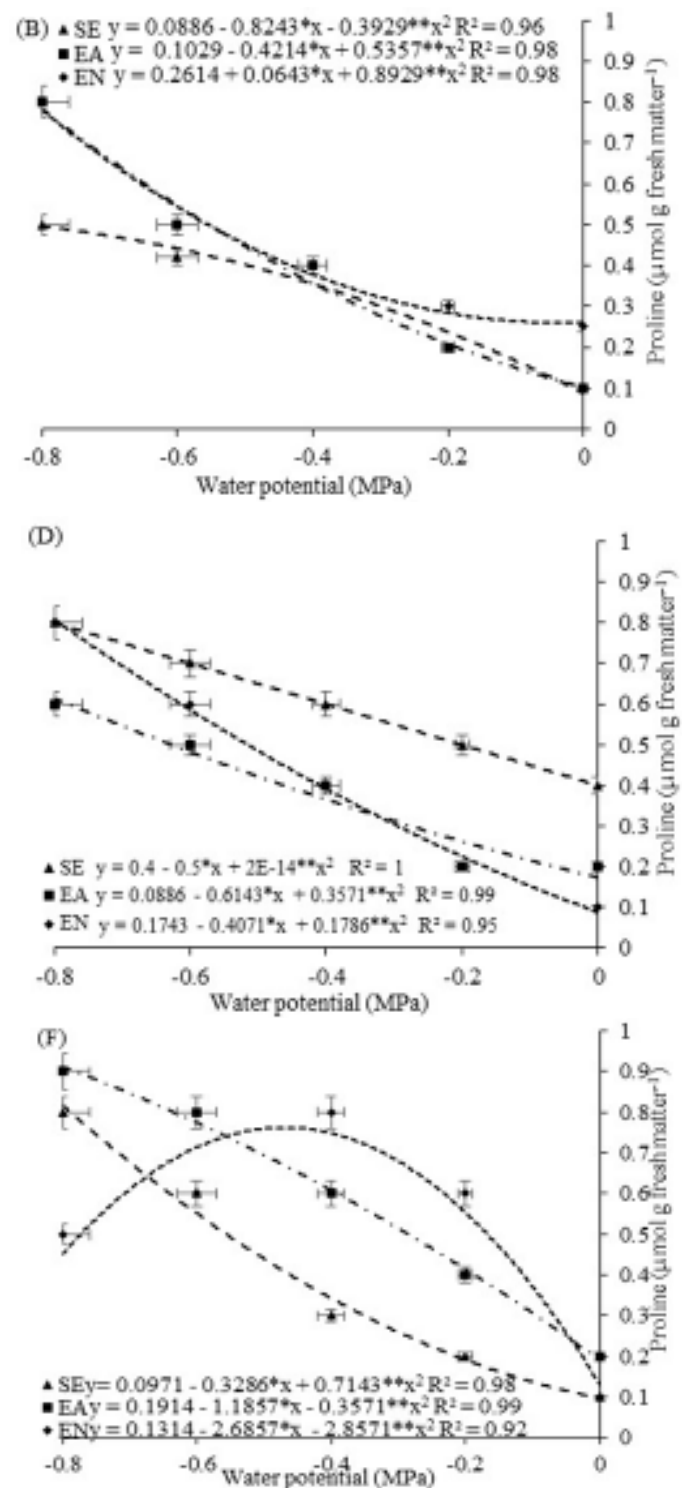

Figure 4. Activity of the enzyme ascorbate peroxidase - APX (A, C and E), Proline - PRO (B, D and F) of the cowpea cultivars: 'BRS Itaim' (A and B), 'BRS Aracê' (C and D) and 'BRS Potengi' (E and F), conditioned during the pre-sowing and subjected to different water potentials induced by PEG 6000. NI - no imbibition; IPW - imbibition in purified water and IPN - imbibition in nitrate.

Rev. Caatinga, Mossoró, v. 30, n. 4, p. 928 - 937, out. - dez., 2017 
This increase in APX L activity may have allowed greater control of the levels of hydrogen peroxide in the cell, avoiding damage caused by oxidative stress, which induces the cultivar to adapt to the water deficit, with significant reflexes on the accumulation of TDP (Figure 4, A, C, and E).

Conversely, there was a significant effect of IPN on APX L activity in the cultivar BRS Potengi, which was greater in seedlings subjected to the more negative potentials $(-0.8 \mathrm{MPa})$ and at $0 \mathrm{MPa}$ (Figure $4 \mathrm{E}$ ). For the other cultivars (BR Itaim and BRS Aracê), the increments caused by the PN application were observed at the intermediate potentials $(-0.4$ to $-0.8 \mathrm{MPa}$ ) (Figure 4, A, C, and E).

APX is a central component of the glutathione-ascorbate cycle with an essential role in intracellular control of ROS levels (SHARMA et al., 2012). APX has greater affinity for $\mathrm{H}_{2} \mathrm{O}_{2}$ than CAT, using two ascorbate molecules to reduce hydrogen peroxidase to water, with simultaneous generation of two molecules of monohydroascorbate. APX expression was higher in plants during the different stress conditions, which may be an important mechanism of control in the overgeneration of ROS (GILL; TUTEJA, 2010; SHARMA et al., 2012).

In the present study, the decrease in water availability gradually increased the concentration of free proline in the leaves (PRO L) of the cowpea cultivars (Figure 4, B, D, and F), regardless of the conditioning, which is consistent with the behavior observed in various crops subjected to water deficit, which include cowpea (COSTA et al., 2011; SILVA, 2014), common bean (AGOSTINI; MACHADO-NETO; CUSTÓDIO, 2013; YAMAMOTO et al., 2014), pigeon pea (MONTEIRO et al., 2014), and sunflower (BALOĞLU et al., 2012).

Regarding the types of conditioning, the lowest PRO L concentrations were obtained in seedlings from seeds with imbibition, especially in distilled water, a result contrary to that observed in seedlings from seeds without imbibition (Figure 4). In comparison to ED, the IPN treatment improved the PRO L accumulation in the cowpea cultivars, suggesting that PN participates in the activation of the osmoregulatory mechanism of the crop. A similar behavior was observed in common bean plants exposed to water deficit induced by PEG (AGOSTINI; MACHADO-NETO; CUSTÓDIO, 2013; YAMAMOTO et al., 2014).

The cultivars with highest PRO L concentration (BRS Itaim and BRS Aracê) achieved the best results for the parameters of germination, growth, and phytomass accumulation (Figures 1 and 2 ), in addition tohaving higher antioxidant activity (Figure 3). Thus, it can be inferred that proline acts as a signaling molecule for water stress in cowpea, and its concentration is directly proportional to the level of damage. Monteiro et al. (2014) report that proline is a biochemical and physiological indicator of the effects of salt and water stresses on pigeon pea seedlings; however, these authors did not observe improvements in the growth parameters with the increase of proline in pigeon pea plants under more severe stress.

\section{CONCLUSIONS}

The genotypic variation of cowpea seeds in solution with osmotic concentration potentials of -0.4 MPa PEG 6000, soaked in nitrate, promotes an increment in germination percentage, emergence speed index, seedling height, activity of SOD, CAT, APX, and proline. Among the cultivars studied, BRS Itaim better tolerates the reduction of water potentials with the PN application, given the increase in the activity of the antioxidant enzyme, CAT, in cowpea seedlings.

\section{ACKNOWLEDGMENTS}

To the State University of Paraíba (UEPB) and the Laboratory (ECOLAB), for providing the facility and staff; to the National Council for Scientific and Technological Development (CNPq), for granting the scholarship (DCR) and financial support, through the Paraíba Research Support Foundation (FAPESQ).

\section{REFEERENCES}

AGOSTINI, E. A. T.; MACHADO-NETO, N. B.; CUSTÓDIO, C. C. Induction of water deficit tolerance by cold shock and salicylic acid during germination in the common bean. Acta Scientiarum Agronomy, Maringá, v. 35, n. 2, p. 209-219, 2013.

ANDRADE JÚNIOR, W. P. A. et al. Efeito do nitrato de potássio na redução do estresse salino no meloeiro. Revista Caatinga, Mossoró, v. 24, n. 3, p. 110-119, 2011.

BALOĞLU, M. C. et al. Antioxidative and physiological responses of two sunflower (Helianthus annuus) cultivars under PEG-mediated drought stress. Turkish Journal of Agriculture and Forestry, Ankara, v. 36, n. 6, p. 707-714, 2012.

BATES, L. S.; WALDREN, R. P.; TEARE, I. D. Rapid determination of free proline for water-stress studies. Short communication. Plant and Soil, Cham, v. 39, n. 1, p. 205-207, 1973.

BEAUCHAMP, C.; FRIDOVICH, I. Superoxide dismutase - improved assays and an assay applicable to acrylamide gels. Analytical Biochemistry, New 
York, v. 44, n. 1, p. 276-287, 1971.

BRASIL. Ministério da Agricultura, Pecuária e Abastecimento. Regras para Análise de Sementes. Secretária de Defesa Agropecuária. Brasília: MAPA/ ACS, 2009. 395 p.

CARVALHO, N.; NAKAGAWA, J. Sementes: Ciência, tecnologia e produção. 4. ed., Jaboticabal, SP: 2000.588 p.

CARVALHO, R. I. N.; CARVALHO, D. B. Germinação de sementes de um ecótipo de paspalum da região de Guarapuava- Pr. Semina: Ciências Agrárias, Londrina, v. 30, n. 4, p. 1187-1194, 2009.

COSTA, R. C. L. et al. ABA-mediated proline synthesis in cowpea leaves exposed to water deficiency and rehydration. Turkish Journal of Agriculture and Forestry, Ankara, v. 35, n. 3, p. 309-317, 2011.

CUSTÓDIO, C. C.; SALOMÃO, G. R.; MACHADO NETO, N. B. Estresse hídrico na germinação e vigor de sementes de feijão submetidas a diferentes soluções osmóticas. Revista Ciência Agronômica, Fortaleza, v. 40, n. 4, p. 617-623, 2009.

FREIRE FILHO, F. R. Feijão-caupi no Brasil: Produção, melhoramento genético, avanços e desafios. 1. ed. Teresina, PI: EMBRAPA MEIO-NORTE, 2011. 84 p.

GILL, S. S.; TUTEJA, N. Reactive oxygen species and antioxidant machinery in abiotic stress tolerance in crop plants. Plant Physiology and Biochemistry, Amsterdã, v. 48, n. 12, p. 909-930, 2010

GIROTTO, L. et al. Tolerância seca de genótipos de trigo utilizando agentes indutores de estresse no processo de seleção. Revista Ceres, Viçosa, v. 59, n. 2, p. 192-199, 2012.

GUIMARÃES, M. A.; DIAS, D. C. F. S.; LOUREIRO, M. E. Hidratação de sementes. Trópica - Ciências Agrárias e Biológicas, Chapadinha, v. 2 , n. 1, p. 31-39, 2008.

HÄTER, L. S. H. et al. Physiological and biochemical performance of sunflower seeds subjected to different osmotic potentials. Revista Brasileira de Ciências Agrárias, Recife, v. 9, n. 1, p. 1-6, 2014.

HE, Q. et. al. Endogenous salicylic acid levels and signaling positively regulate Arabidopsis response to polyenthylene glycol-simulated drought stress. Journal of Plant Growth Regulation, New York, v. 33, n. 4, p. 871-880, 2014.
KAISER, I. S. et al. Efeito de liberadores de óxido nítrico na qualidade fisiológica de sementes de repolho sob salinidade. Revista Ceres, Viçosa, v. 63, n. 1, p. 39-45, 2016.

LISAR, S. Y. S. et al. Water stress in plants: causes, effects and responses. In: RAHMAN, I. M. M. (Ed.). Water Stress. Rijeka: Intech, 2012. cap. 1, v. 1, p. $1-14$.

LOPES, J. C.et al. Germinação e vigor de sementes de pau d'alho sob estresse salino. Brazilian Journal of Forestry Research, Colombo, v. 35, n. 82, p. 169-177, 2015.

MENDES, R. M. S. et al. Relações fonte-dreno em feijão-de-corda submetido à deficiência hídrica. Revista Ciência Agronômica, Fortaleza, v. 38, n. 1, p. $95-103,2007$.

MICHEL, B. E. KAUFMANN, M. R. The osmotic potential of polyethylene glycol 6000. Plant Physiology, Rockville, v. 51, n. 5, p. 914-916, 1973.

MONTEIRO, J. G. et al. Crescimento e conteúdo de prolina em plântulas de guandu submetidas a estresse osmótico e à putrescina exógena. Pesquisa Agropecuária Brasileira, Brasília, v. 49, n. 1, p. 18-25, 2014.

MOTERLE, L. M. et al. Influência do estresse hídrico sobre o desempenho fisiológico de sementes de híbridos simples de milho-pipoca. Ciência e Agrotecnologia, Lavras, v. 32, n. 6, p. 1810-1817, 2008.

NAKANO, Y.; ASADA, K. Hydrogen peroxide is scavenged by ascorbate-specific peroxidases in spinach chloroplast. Plant and Cell Physiology, Oxford, v. 22, n. 5, p. 867-880, 1981.

NASCIMENTO, S. P. et al. Tolerância ao déficit hídrico em genótipos de feijão caupi. Revista Brasileira de Engenharia Agrícola e Ambiental, Campina Grande, v. 15, n. 8, p. 853-860, 2011.

PRAZERES, S. S. et al. Crescimento e trocas gasosas de plantas de feijão-caupi sob irrigação salina e doses de potássio. Revista Agr@ambiente, Boa Vista, v. 9, n. 2, p. 111-118, 2015

REHMAN, S. et al. The effect of sodium chloride on germination and the potassium and calcium contents of Acacia seeds. Seed Science and Technology, Zurich, v. 25, n. 1, p. 45-57, 1996.

SILVA, A. R. F. Componentes de produção e fisiológicos em ecótipos de Vigna sob reposição hídrica. 2014.86 f. Dissertação (Mestrado em Ciências Agrárias; Área de concentração em 
Agrobioenergia e Agricultura Familiar) Universidade Estadual da Paraíba, Campina Grande, 2014.

SHARMA, P. et al. Reactive oxygen speciaes, oxidative damage, and antioxidativa defense mechanism in plants under stressful conditions. Journal of Botany, Cairo, v. 2012, n. 1, p. 1-26, 2012.

SHARMA, P.; DUBEY, R. S. M. Modulation of nitrate reductase activity in rice seedlings under aluminium toxicity and water stress: role of osmolytes as enzyme protectant. Journal of Plant Physiology, Amsterdã, v. 162, n. 8, p. 854-864, 2005.

SUDHAKAR, C.; LAKSHMI, A.; GIRIDARAKUMAR, S. Changes in the antioxidant enzyme efficacy in two high yielding genotypes of mulberry (Morusalba L.) under $\mathrm{NaCl}$ salinity. Plant Science, Amsterdã, v. 161, n. 3, p. 613-619, 2001.

TAIZ, L.; ZEIGER, E. Fisiologia vegetal. 5. ed. Porto Alegre, RS: Artmed, 2013. 918 p.

YAMAMOTO, C. J. T. et al.Water-deficit tolerance induction during germination of Jalo Precoce bean (Phaseolus vulgaris L.) cultivar. Acta Physiologiae Plantarum, Berlin, v.36, n.11, p.2897-2904, 2014. 